\title{
Rupture and Call: Famine Encounters from Contemporary Irish and Ukrainian Women in the Arts
}

\author{
Emily Holt \\ Seattle Pacific University \\ Grace Mahoney \\ University of Michigan
}

\begin{abstract}
In this paper, the authors examine artistic engagement with famine memory by six women artists working in the Irish and Ukrainian contexts: Alanna O'Kelly, Paula Meehan, Mary McIntyre, Oksana Zabuzhko, Nataliia Vorozhbyt, and Lydia Bodnar-Balahutrak. Representing famine in artistic form is mired in ethical challenges. When interpreted at the level of national narratives, such histories can become identities and form a part of the collective ethos. Work by women artists is critically positioned to challenge the strong association between the feminine and the nation found in nationalistic discourses in both Ireland and Ukraine. The artists examined here work across genre and media, yet all eschew stereotypical imagery and prescribed vocabulary for representing famine, thus engaging in the complexities such representation offers. Framing their analysis with Bracha Ettinger's concept of aesthetic wit(h)nessing, the authors find in the work of contemporary female artists in Ireland and Ukraine opportunities to encounter and grapple with famine memory without immediate recourse to commemoration or resolution. It is thus in the work of women artists today that one finds both a rupture and a call: a rupture to representing famine memory in modes that promote ownership and invite appropriation, and a call to consider what practices, rituals, and acts of wit(h)nessing have sustained life and remembered the dead after famine.
\end{abstract}

Keywords: famine, women, art, trauma, representation, aesthetics.

$\mathbf{I}$

n the 1997 essay "Famine Roads," Eavan Boland traces her decision to write about the Irish Famine of 1845-52 in narrative rather than lyric form despite her prominent identity as a lyric poet. "Somehow," she writes, "I wanted to make a distance and respect for the event which would prevent language appropriating it" (Boland 222). Deeply attuned to the ways in which the emotional immediacy and often fragmented use of time in the lyric poem could occlude actual human histories, Boland not only raises essential questions regarding ethical representation, but also highlights the formal and aesthetic concerns that arise when engaging with collective histories of human suffering. As David Rieff has argued in his provocative In Praise of 
Forgetting: Historical Memories and Its Ironies, once collective memories are transmitted for more than three or four generations, they can no longer be called memory "other than metaphorically" (106). With traumatic memories in particular, internal processing and communal transmission are highly metaphoric processes. Research now confirms that the physiological and neurological fragmentation that often follows trauma "lives on" in the body in metaphoric ways. ${ }^{1}$ While trauma, like the lyric, "stops" time, traces or "parts" of trauma persist in the body and the psyche, echoing long after the original threat (Voigt 18). ${ }^{2}$ However, despite the fact that traumatic memory immediately raises questions of form and aesthetics, discourse on famine representation and memorialization often centres around traditional modes of psychoanalytic criticism, often at the exclusion of formal or aesthetic criticism. In places such as Ireland and Ukraine, where histories of mass starvation continue to resonate with ongoing political conflict, literary and visual art critics are called to consider how trauma "lives on" in the collective histories of contemporary artists.

In Ireland and Ukraine, famine memory remains outside of normative discourse on collective identities and the nation. Although the major famines from each country are recognized by historical monikers-in Ireland, An Gorta Mór (1845-52), and in Ukraine, Holodomor (1932-33)-in both contexts, famine memory has been displaced and marginalized, not only as a result of trauma, but also as a result of repressive and colonialist policies, emigration, wilful forgetting, and temporal distance. ${ }^{3}$ In approaching these displaced memories, Joseph Valente warns against relying solely on repression-based trauma theories which can enable the collective appropriation of memory by those who did not experience the effects of mass traumas and/or who do not carry family histories of such trauma (182). Positing an approach rooted in dissociative symptomology, Valente echoes advances made in clinical and research psychology, including new, neurobiologically informed approaches to trauma and trauma treatment. ${ }^{4}$

\footnotetext{
${ }^{1}$ In the words of trauma researcher Bessel van der Kolk, "the body keeps the score" (qtd. in Fisher 1).

2 For a discussion of lyric form, see Voigt, The Flexible Lyric. "In the lyric," Voigt writes, "you can stop time; you pick that moment of intensity and hold it. The narrative moves through time" (135).

${ }^{3}$ For example, Joseph Valente argues that it is only by attending to "the complex relay system between traumatic shock and societal fracture" that we may begin to see the ways in which the Irish Famine has remained "the other," a historical "event" that rarely fits cleanly within nationalist histories yet has enacted massive historical, cultural, and linguistic changes in Ireland (186-87).

${ }^{4}$ Dissociative symptomology refers to the diffuse range of natural human responses to life-threatening danger-ranging from sympathetic and parasympathetic arousal
} 
Through the lens of the Structural Dissociation model, proposed by Onno van der Hart, Ellert Nijenhuis, and Kathy Steele in 2000, post-traumatic dissociative fragmentation is viewed as a survival-oriented adaptive response; in such a model, expressions of traumatic memory-whether in ordinary life or in art-are transformed from signs of risk or pathology to proof of survival, or even to creative adaptation (qtd. in Fisher 9). ${ }^{5}$ Such an approach, in which symptomology and adaptative responses are "proof enough" of the way trauma lives in an individual, family, or community, is particularly illuminating in the case of Holodomor, where survivor memory continues to shape familial, national, and political discourse. To attend more fully to the formative nature of famine memory in Ireland and Ukraine, a new critical approach is needed: one attentive to the formal issues that arise when artists attempt to shape, convey, and carry traumatic memory into art, and one that acknowledges the role of dissociation in encountering traumatic memory.

Drawing on Griselda Pollock's application of the matrixial theory of Bracha L. Ettinger, we advance a feminist psychoanalytic framework to examine works of art that perform an "aesthetic wit(h)nessing" of famine memory. ${ }^{6}$ Ettinger's concept of aesthetic wit(h)nessing both metaphorically and linguistically invites readers, viewers, and critics to consider how witnessing may also be an act of being with the "other" (Pollock, After-Affects 13). In this encounter with the "other" — that is, art that bears "traces of

and hypoarousal (fight, flight, freeze, submit, cry for help), to more complex, habituated responses such as forgetfulness and amnesia, depersonalization, derealization, dissociative fugue, identity confusion, and identity alteration (Fisher 26,148 ).

${ }^{5}$ In this model, well accepted across Europe, structural dissociation is a "survivaloriented adaptive response to the specific demands of traumatic environments, facilitating a left brain-right brain split that supports the disowning of 'not me' or trauma-related parts and the ability to function without awareness of being traumatized. The splitting also supports development of parts driven by animal defenses that serve the cause of survival in the face of danger" (Fisher 4, 9). Working in this multi-conscious model, clinician and author Janina Fisher combines cuttingedge trauma treatments, including Sensorimotor Psychotherapy, the Internal Family Systems model, mindfulness-based therapies, and clinical hypnosis, to assist survivors in creating a sense of internal safety.

${ }^{6}$ Bracha Ettinger is an Israeli-born French artist whose artwork engages with the traumas, silences, and erasures of the Holocaust, and whose writings re-envision the feminine other, or Matrix, within psychoanalysis. The Matrix, or the "primordial human capacity for co-affection and transsubjective sharing," supplements Lacan's theory of the Phallus, the Real, the Imaginary, and the Symbolic (Pollock, After-Affects 14). Rather than beginning in the logic of the psychoanalytic cut, in the rejection of the abject maternal sphere, the matrixial is attuned to the prenatal and prematernal space that each human experiences before birth (Pollock, After-Affects 14-15). 
trauma" - the viewer is pulled, drawn, and moved to know and even to digest the trauma of the subject, the figure, or the artist (Pollock, After-Affects xxviii, 19). In this framework, both artist and reader/viewer/critic approach trauma not with the aim to cure but to meet at a "borderspace becoming threshold" (Pollock, After-Affects 15). Trauma is thus not understood as "an anterior or exterior, generating source of imagery for a self-aware, knowing subject" (Pollock, After-Affects xxvii). "Trauma," Pollock writes, "is the notyet-experienced non-thing towards which a lifetime of making art might be unknowingly journeying" (After-Affects xxvii).

Beginning within the matrixial sphere changes not only the very nature of our fundamental relations, but also, necessarily, the nature of our art. Ettinger explains: "The non-I is not Other but, like the $I$, is a becoming-in-terwith, and therefore, a clear cut between the living and the dead, the pure and the impure, so basic in the Phallus, is beyond the matrixial scope" (82). Through approaching art as a matrixial space of becoming, one can begin to imagine a more ethical "trans-subjectivity between I and non-I, me and the stranger, not just at the borderspaces of becoming but also of disappearance and of dying" (Pollock, "Thinking" 20). In such a future, our connections to widespread disappearance and death as experienced during famine might be transformed-not rejected or denied, but rooted, instead, in a relationship to an "other" to which we are linked and called to wit(h)ness.

In choosing to focus on the work of contemporary female artists in Ireland and Ukraine, we do not imply a direct conflation between the artists' gender, their artistic style, or how directly or indirectly they approach the multi-layered traumas of famine and famine memory. Rather, our choice disrupts the higher incidence of male representation in work commemorating famine memory and its critical reception. ${ }^{7}$ Our focus on women also complicates the strong association between the feminine and the nation found in nationalistic discourses and representations of famine in both countries. Though approaching work by female artists inevitably highlights systems and dialogues of sexist oppression, our stance of reparative reading enables us not only to locate signs of oppression but also to witness how individuals and communities manage not only to survive but to find sustenance from national, cultural, and linguistic systems whose aims have been to suppress and oppress. ${ }^{8}$ In looking at both national contexts in an intergeneric framework-juxtaposing poetry and lens-based media alongside theatre and painting, prose, and music-we intervene in single-

\footnotetext{
7 Emily Mark-Fitzgerald observes that the same artists are often commissioned for commemorative efforts in Ireland and the U.S. "The Irish Famine" 158). These artists are also predominantly male.

8 For a discussion of "paranoid" versus "reparative" reading practices, see Sedgwick 149-50.
} 
genre studies which, often inadvertently, do not acknowledge that trauma lives in the body and moves in society in multi-sensory ways. Throughout, we discuss both clinical and psychoanalytic manifestations of trauma; we do so to respect the ways in which the broader field of trauma studies moves between and integrates the two, and to honour the reality that trauma does not live neatly in any category.

We look at manifestations of famine memory and trauma in the works of three contemporary Irish artists-Alanna O'Kelly, Paula Meehan, and Mary McIntyre; two contemporary Ukrainian artists-Oksana Zabuzhko and Nataliia Vorozhbyt; and a Ukrainian-American artist-Lydia BodnarBalahutrak. Beginning in wit(h)nessing rather than memorialization, the works of these artists not only reflect acts of sustenance and mourning articulated via the body, ritual, and landscape, but also disrupt the very assumptions of what it means to live with and within a history of hunger. In these works one finds both a rupture and a call that uncannily mirrors the "rupture and repair" model of trauma treatments: a rupture to representations of famine memory that promote ownership and invite appropriation, and a call to consider what practices, rituals, and acts of wit(h)nessing have sustained life and remembered the dead after a famine. ${ }^{9}$

\section{IRELAND}

The Great Famine of 1845-52 (An Gorta Mór, the Great Hunger), resulted in the loss of close to three million people-more than one million died by starvation and related diseases, and more than two million emigrated to the United States, Australia, and England, a migratory trend that continued at high rates through 1921. Environmental triggers were compounded by the effects of imperial rule, exploitative land use, and the mass exportation of food to England.

Today, debates and conversations continue regarding how adequately, or how authentically the Famine has been memorialized, commemorated, and evoked in artwork. While it is true that older individuals in Ireland today

\footnotetext{
9 In attachment literature, "rupture and repair" describes the process of infants naturally building resilience when exposed to an experience just outside their comfort zone. When followed by an act of repair by the caregiver (soothing, encouragement, reassurance, distraction), the attunement between infant and caregiver increases infant comfort and the ability to tolerate future discomfort (Fisher 227). While the artworks we explore are not comforting, nor are they directed at children, they do disrupt dominant modes of representation, narrative, and thinking, and thus create space for alternative, productive, and potentially reparative ways of engaging famine memory.
} 
would know personally of the Famine only through their greatgrandparents' experience, even metaphoric famine memory in Ireland is complicated by wide-scale traumas in twentieth century Ireland-ranging from the Irish War of Independence (1919-21), the Irish Civil War (192223), and the Troubles (1968-98) to the more recent traumas of widespread physical and sexual abuse in industrial schools and "mother and baby homes" and the degrading housing conditions of asylum-seekers and refugees in direct provision. ${ }^{10}$ As Judith Herman has observed in countries emerging from civil war or dictatorship, restoring a sense of social community requires both a public forum where victims can speak their truth and experience a formal recognition of their suffering, and an organized effort to hold individual perpetrators responsible for their crimes (242). In the Irish context, organized efforts for recognition and restitution have historically come second to colonial power, state interest, and the diffuse yet hierarchical power of the Catholic Church.

Further complicating commemoration or engagement with famine memory is the fact that the events of 1845-52, and the migratory fallout, have been appropriated by nationalistic campaigns, sectarian conflict, and more recently by social media campaigns mobilized to contrast Irish suffering against that of those migrating to or seeking asylum in Ireland. ${ }^{11}$ In light of the problematic recasting of 1880s-90s eviction photography as "Famine images" by nationalist leaders and sympathizers in the 1880s land wars, Emily Mark-Fitzgerald has called for a denaturalization of the "imaginary economy" - that is, a reconsideration of the conditions of an image's making and being seen ("Photography" 121,127). Such a process, Mark-Fitzgerald argues, will enable viewers to examine "Famine images" as constructed narratives rather than as historical proof ("Photography"123).

The form of commemoration thus raises as many questions as does the nature of such efforts. While poetry and oral storytelling have often held an esteemed place in Irish culture and Famine memorialization, contemporary expectations of documentary photography increasingly manifest as a desire for visual evidence of Famine suffering. ${ }^{12}$ Though Justin Carville argues that

\footnotetext{
10 Scholars and communities in Ireland debate the exact "ending" of the Troublesin light of ongoing socio-economic struggles in the region, the uncertainty of border issues in Brexit, and, most pressingly, the January 2017 collapse of power-sharing in the devolved Northern Irish Assembly.

11 For more on the relationship between the Famine silence and nationalistic discourse in Ireland, see Lloyd, "Adulteration and the Nation" 112-14, and Ireland after History, chapters 1 and 2.

12 Visual art made in dialogue with the Famine has recently come to the forefront of public attention and research, in part owing to the efforts of Ireland's Great Hunger Museum, which organized Coming Home: Art \& the Great Hunger, an exhibit running
} 
the Famine can be witnessed in "the form if not the content" of nineteenth century Irish photographs of picturesque ruins and landscapes free of human figures, Mark-Fitzgerald has pointed out that these formal choices speak not so much to the absence of the Irish peasant from the landscape but rather to the ways in which pictorial conventions of early visual media limited representation of the "Famine body" (Carville 66; Mark-Fitzgerald, "Photography" 121, 126). Even as significant progress has been made in efforts to commemorate or memorialize the Famine, lesser attention has been paid to artistic engagement that attempts to process fragmented Famine memory, problematize representations of "the Famine body," or counter dominant Famine narratives.

Whereas the commemorative or memorial act attempts to fix meaning and narrative in order to set boundaries on historical memory-often motivated by justice or a desire for healing-the artistic act, through Pollock's lens, is reconceived as a working-toward: a dually conscious and unconscious process in which emotions, affective states, and even traces of trauma arise and find physical expression and/or associative connection (After-Affects xxvii). Attending to artwork from this position, rather than from one focused on commemoration, enables us to consider how the Famine memory lives and will continue to live on while historical distance increases and the sharpness of traumatic memories alters. In the contemporary works of O'Kelly, Meehan, and McIntyre, one finds both an engagement with the ethics of corporal representation and a disruption of what Mark-Fitzgerald terms the visual "vocabulary" of the Famine memorialization - thatched cottages, emigrant ships, and emaciated figures ("The Irish Famine" 162). One also finds an important disruption of dominant tropes of maternal inadequacy and abjection, often found in commemorative work of the Famine. ${ }^{13}$ In moving by degree of direct engagement with famine memory-rather than moving chronologically by the publication of each work - we will highlight both where direct naming of the Famine memory enables artists and viewers to create and revive lost mourning practices, and where even associative, ambiguous, or indirect evocation of the Famine memory remains productive and generative for artists grappling with contemporary social issues. ${ }^{14}$

throughout Ireland from 2018 to 2019. The museum is located at Quinnipiac University in Hamden, Connecticut, and the exhibit was displayed in Dublin Castle, West Cork Arts Centre in Skibbereen, and Cultúrlann Uí Chanáin in Derry, Northern Ireland.

${ }^{13}$ For an analysis of the portrayal of women in post-Famine literature, see Kelleher.

14 Included here are only artists who live in Ireland; this is not to ignore the commemorative and artistic work made in diasporic communities, but instead to focus on the ways in which famine memory engages with contemporary social issues 
Alanna O'Kelly's film, Sanctuary/Wasteland (1994), announces its connection to the Famine: indirectly within the film itself, and directly for those who view the accompanying gallery text. The film centres on the erosion of Teampall Dumach Mhór at Thallabawn, Co. Mayo, a mound that was initially part of a sixth-century monastic settlement and was later a Famine burial site. ${ }^{15}$ Though from Wexford, not Mayo, O'Kelly recalls hearing as a child of a similar history of "dinnseanchas": a local field left fallow because it was said to be a Famine burial site (Kelly 40). ${ }^{16}$ An abstract, multisensory work of art, Sanctuary/Wasteland dissents from the monumentfocused and often highly localized practice of contemporary Famine memorialization, moving toward what Mark-Fitzgerald describes as a more "unresolved" formal approach ("Photography" 134). Drawing together Famine narrative and material memory from across the island, O'Kelly begins to reverse the fragmented and disconnected ways the Famine has been remembered in Ireland.

O'Kelly heightens this sense of unresolution by setting the visual movement to a keen-a vocal funeral lament, which, along with other mourning and burial practices, was instrumental to pre-Famine Irish culture, but due to the rate and types of death was largely silenced by the Famine (Lloyd, "The Memory of Hunger" 36, 44; Kelly 40). ${ }^{17}$ Incorporating her own breathwork into the film's audio, O'Kelly not only integrates her own body into the work, but also responds to the persistent contemporary desire for an immediate and experiential entry into the sometimes sanitized horror of the distant past. However, by challenging filmic norms and by avoiding any depiction of the human body, 0'Kelly effectively resists objectification and containment of physical suffering. The very duality of the film's name speaks to the way in which it creates a liminal, borderspacebecoming-threshold between self and other, and life and death.

Experientially, the approximately eleven-minute film invites an immersion into sonic and visual patterns that, while rooted in a site-specific engagement with local Famine memory, also evoke memories of labour, birth, and loss. Within the first twenty-five seconds, the primary image of a mountain is overlaid with the appearance of a jaw-like crypt in the bottom

that most directly affect those who reside in Ireland. Examining the possible influence of survivor's guilt in diasporic work would be a productive focus for future analysis, as would identifying the way work by immigrants to Ireland engages Famine memory.

15 Known as "sanctuary" to seventeenth-century mapmakers, the site was later called "the Wastelands" by local people in the nineteenth and twentieth centuries (Irish Museum of Modern Art, qtd. in Kelly 40).

16 "Dinnseanchas," Irish for "place wisdom" or lore.

17 O’Kelly learned how to keen for earlier work (O’Kelly, qtd. in Kelly 40). 
right-hand corner of the screen. The nearly infrared colouring of the image evokes an image from an ultrasound scan, but rather than a fetus there appears an image of rope, kelp, metal pipe, or bones. Initial, tinny vibrations give way to a quieter thrumming and a man's rhythmic mumbling, punctuated a minute later with a woman's cry and the overlay of her aspirated lilting and sighs. As the film progresses, images of a farther mountain and shore appear in the top corners of the screen, images that appear and recede as the sound of rushing water builds and fades.

Figure 1. Alana 0'Kelly, Sanctuary/Wasteland, 1994. Irish Museum of Modern Art, Purchase 1997; image permission of the artist.

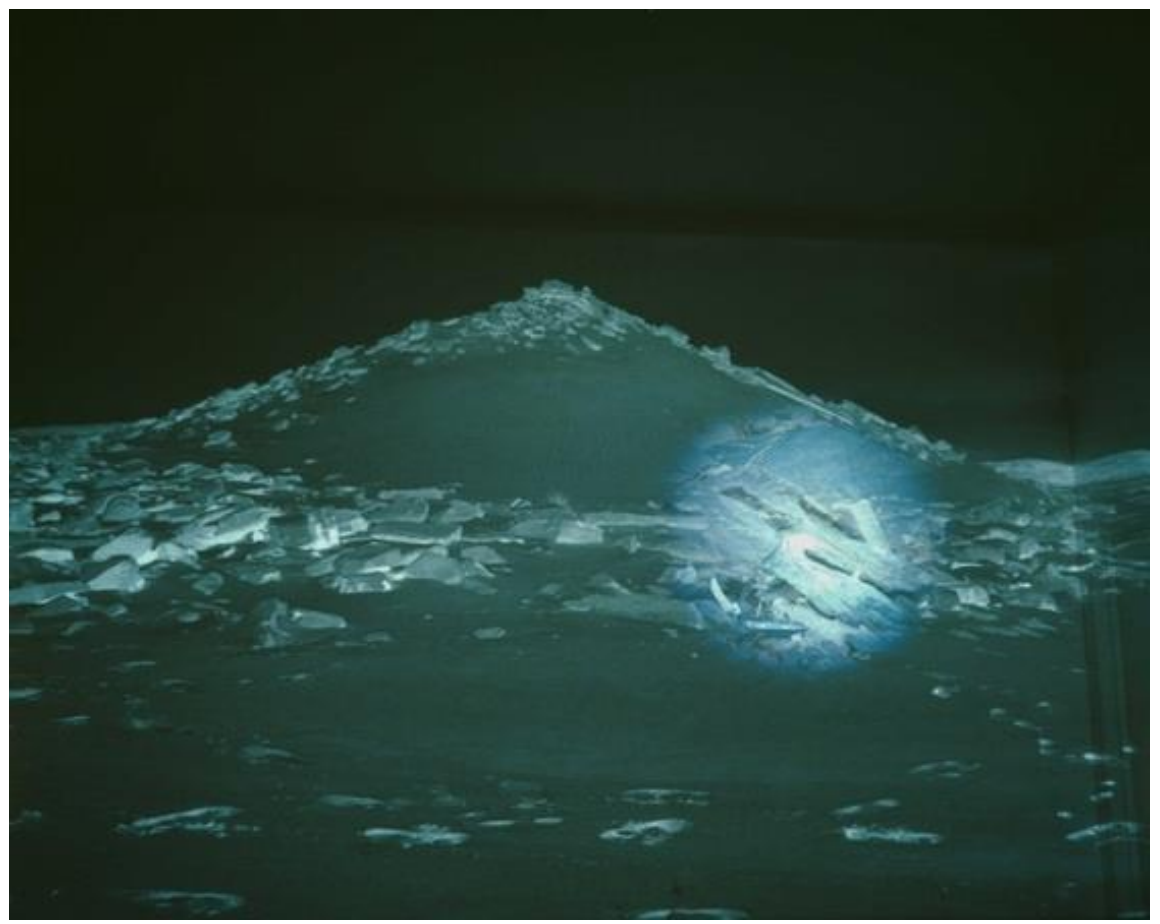

At the film's midpoint, the landscape disappears entirely, the overlapping lilts and voices sound at once, and the drum changes beat. Cryptlike images of alternating reds, pinks, and teals begins to appear and disappear as the woman's voice becomes more prominent, confronting the viewer with an intensity of aural and visual sensations. As the yonic image appears and reappears, it becomes clear that one is viewing buried bones. Near the end of the film, multiple women's voices intermingle until the peak 
of a distant mountain appears, voices fade, and the thrumming gives way to the sound of rushing water.

O'Kelly's blurring of the womb and a burial site places the viewer in visual uncertainty, even as they are swept up in the lyrical sounds. In this fragile space of simultaneous sensations, the viewer's inability to pin down a single meaning enables a spontaneous, affective reaction. For some viewers, the film may speak more to the relationship between humanity and the landscape, or the sound of a woman's exhalations may evoke the labour of bringing life into the world. For those who know the history of Teampall Dumach Mhór, it may open a temporary, fleeting space in which to encounter the indistinct borders between the living and the dead. O'Kelly maintains a non-appropriative relationship to the local history, using neither direct nor figurative representation to incorporate the suffering body into the present. Instead, by evoking shared yet unable-to-be-recalled experiences of birth and dying, and structuring the film around the cycles of a woman's lilting and breathing, O'Kelly roots this liminal engagement with birth, loss, and death in and near the female body without the objectifying elisions of nationalistic, patriarchal, or religious ideology-ideology that poet Paula Meehan confronts directly.

As the 2013-16 Poetry Chair of Ireland, Paula Meehan has been and remains an active force in the public life of poetry in Ireland. Though much of her work addresses issues of women's rights and the struggles of workingclass communities in Ireland, her work is rarely associated with the Famine. In the 1986 poem "Hunger Strike" (Reading the Sky), however, Meehan addresses the ways in which nationalistic ideology has elided memory of the Famine in order to advance the agendas of an independent republic. She also implicates the ways in which the tradition of hunger-striking in Ireland resonates in a country in which language, mourning practices, and political systems were fundamentally altered by famine. Though the relationship between hunger-striking and famine in Ireland has not been the subject of significant research, Joseph Lennon has argued that the national crisis spurred by Terence MacSwiney's hunger strike and death echoed the endurance narratives of Famine survivors who were elderly and dying in the 1920s (60-61). ${ }^{18}$ In a similar way, the threads of personal and familial memory resurface in the filial memory of Meehan's history and work.

In a 2009 interview, Meehan recalls being immersed as a child in the oral, storytelling tradition of "the old people," effectively entering their "time zone" while listening to their stories from beneath the kitchen table (Randolph 241). "My grandmother's people would have been in the famine, her grandparents," Meehan explains, "and she would have those terrible

18 MacSwiney was elected Sinn Féin Lord Mayor of Cork during the Irish War of Independence. His hunger strike in England's Brixton prison lasted 74 days. 
stories" (Randolph 241). While "Hunger Strike" is dedicated in memoriam to Bobby Sands, the poem's emotional centre evokes the physical and spiritual hungers of ordinary people, and this move between the personal and the public creates the tension on which the poem eventually turns. ${ }^{19}$

Though beginning the poem in the first person plural-thus locating the scale of the poem in a community that waits "hour by murderous hour" to hear news of Sands' strike-Meehan quickly moves to address Sands directly: "In the small cage of your body / You must have remembered / The rude march of history" (9). Subversively using the repetitive elements of a lament, Meehan recalls the pain of a history that now moves "Through the rooms of your past: / Through the kitchen, / Through the parlours, / Through the bedrooms, / Down all the hours" (9). This history disrupts "even lovers / From their raptures," drawing the body away from lifeaffirming intimacy to instrumentalization and sacrifice (9). In the third stanza, the first person enters, and the speaker confesses in a harsh, rhyming consonance and tightly enjambed lines: "I neglected the garden that season, / Took a desultory spate at the hoe / Now and again. I forgot the insistent / Beauty of seeds" (9). Still addressing Sands, she admits to being enthralled to the national drama where "Black and feverish on every front page / Your eyes watched us move / Through our puny acts" (9). Layering images of a garden, harvest, torture, public media, and an ever-present reality of Famine years - fever-Meehan interweaves life and death, public and private, until there are no clear borders.

Returning to the lament, Meehan details listening "At the butchers, at the bread van, / At the bus stops, in the queues: // Any word? Any word? Any word?" (10). Though an anxious participant in this national dialogue, the speaker cannot ignore the cycles of violent symbolism that reign over her working-class community. She observes a man outside the General Post Office, a site of nationalist rebellion, holding a "blown up / Photo of your face" and recalls, "It was the exact / Same face that terrorized my childhood / From the elevated altars of the poor" (10). Remaining focused on the depicted bodies of Sands and of Christ, Meehan reveals the extent to which nationalistic and religious systems instrumentalize corporal suffering and thus elide true social progress. "Was that your magic?" the speaker asks, "Knowing each and all of us / Were reared on such ritual?" (10). As anguish builds and Sands' death draws near, the tone shifts. The speaker states: "My garden ran wild. / The weeds exulted" (10). When an old woman comes by, bringing soda bread and homemade butter "So yellow it hurt to look at," she

\footnotetext{
${ }^{19}$ After enduring years of solitary confinement and beatings in the H-Blocks at Long Kesh prison in Northern Ireland, twenty-seven-year old Bobby Sands led the 1981 Hunger Strike, during which he was elected MP for Fermanagh and South Tyrone. Before he died, he was Commanding Officer of IRA political prisoners in Long Kesh.
} 
is not the "tSeanbhean Bhocht" of national tradition but one who grips "a scapular of a saint / She swore by" (10). ${ }^{20}$ No longer indicting the role of religion in public life but encountering ordinary devotion and tradition, Meehan's speaker softens; the sibilant roll of s's and soft consonants quiets the tone. After this moment of encounter, the poem quickly moves to its end: "She remarked I was losing weight / And looking through the window asked / Did I feel no shame at the rotting harvest" (10). Landing on this harsh aural clip, Meehan pulls away from the speaker's indignation over nationalistic propaganda and moves toward a longer view - the time of the elders, those who recall the blight, and the costs of survival. Through layered narratives and subtle allusions to the Famine, Meehan critiques nationalistic and religious systems that reduce flesh and blood to mere symbols; ultimately, however, she implicates her own speaker's short-sightedness, calling for a return to the wisdom wrought by "those terrible stories." Though a Dublinbased writer, Meehan's weaving together of past and present, north and south, reminds us that the Irish/Northern Irish border complicates how the Famine memory lives with or beside memories of the Troubles.

Though population decline was lower in Ulster, particularly in the 1850s, the Famine affected the entire island (Gregory and Ell 155). Famine memorialization, however, has been concentrated in the Republic of Ireland. Given the complex interplay between nationalist ideology and coerced or instrumentalized silence regarding the Famine, prematurely locating famine memory in work made in the north may invite unproductive and inaccurate comparisons of mass disappearance and loss. The work of Mary McIntyre, however, already divergent from expected modes of interpretation within Northern Irish photography, reveals how, without conflation or appropriation, an artist may enable viewers to draw spontaneous lines of connection to personal experience, their environment, and historical suffering.

Though McIntyre often photographs landscapes with little trace of human life, critical responses to her work are often filtered through the lens of identity in post-Agreement Northern Ireland. ${ }^{21}$ Colin Graham has ventured that the absence of the figure in post-Agreement photography may reflect the way in which focusing on an individual can evoke a sectarian label rather than an individual's personal experience (87). "The portrait-in-thearchive," Graham notes, "also brings with it an insistence on a personal narrative and thus an implication of empathy, or even pity..." (87). In these

\footnotetext{
20 "An tSeanbhean Bhocht" ("the poor old woman") is an eighteenth-century motif used to personify Ireland, one that heralds back to the aisling tradition of Irish poetry and reappeared in twentieth-century drama.

${ }^{21}$ After the 1998 Good Friday Peace Agreement.
} 
terms, McIntyre's omission of the figure can translate to a dis-engagement with issues of identity and a refusal to use narrative to garner empathy.

While such an approach may locate McIntyre within local practices in post-Agreement photography, the minimalistic, highly formal nature of McIntyre's work, and her evocation of lyric space rather than narrative time, invites a critical approach that extends beyond the increasingly narrow confines of identity in Northern Ireland. ${ }^{22}$ When figures appear in McIntyre's images, they are often at a threshold-standing on a bridge, at the water's edge-or are encased by forest, foliage, or fields. These indeterminate, liminal landscapes are rendered through clear, geometric composition, saturated colour, wide depth of field, and low exposures. This close attention to formal composition reflects McIntyre's concern that contextual readings of her work often do not tell the whole story, which she describes as "a wider exploration of haunting traces the human leaves behind" (Reginio et al. 351).

"The Mound" series, in particular, highlights the critical avenues opened when one considers trauma not as a clinical event or set of symptoms but as the "not-yet-experienced non-thing towards which" an artist might be moving. The creation of this series reflects McIntyre's spontaneous, intuitive process: while on her way to make another series focused on fog, McIntyre came across "piles of freshly turned earth," and "felt disturbed by something that appeared to be a kind of burial mound at the side of the road. .." (Tuck 71). The evocative landscape images that result demonstrate McIntyre's unique approach to representations of land, psychological space, and identity in Northern Ireland.

22 We again draw on Voigt's definition of the lyric. 
Figure 2. Mary McIntyre, "The Mound, I" (2009); colour lightjet photographic print, $80 \mathrm{~cm} \times 100 \mathrm{~cm}$; image permission of the artist.

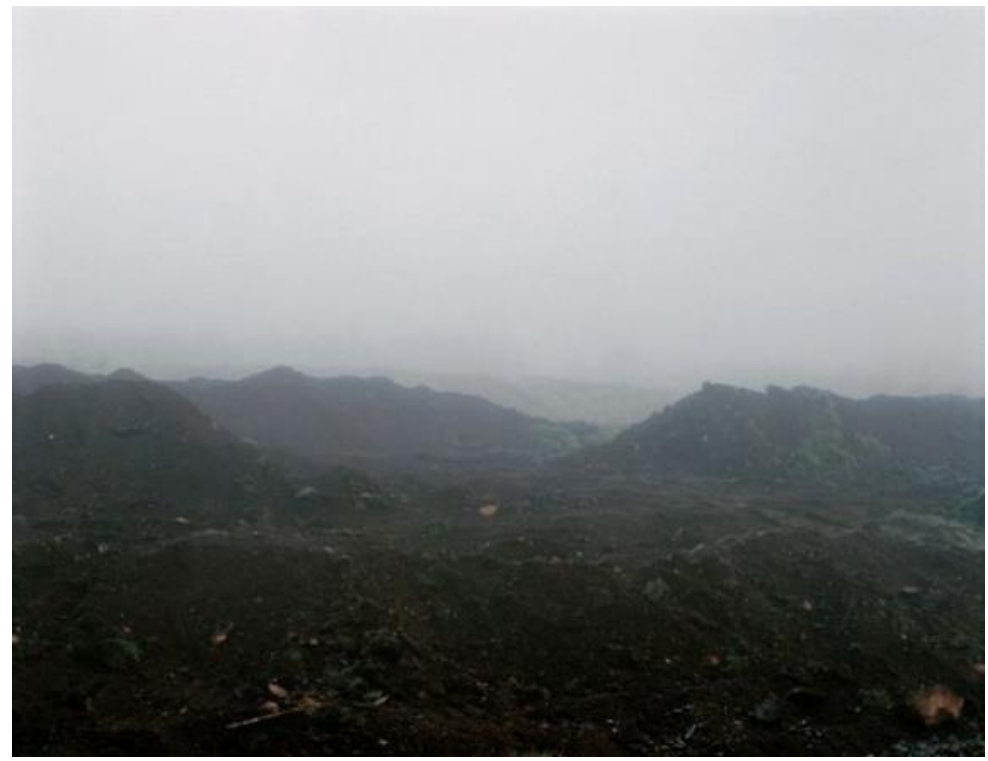

Fig. 3. Mary McIntyre, "The Mound, II," (2009); colour lightjet photographic print, $80 \mathrm{~cm} \times 100 \mathrm{~cm}$; image permission of the artist.

(C) 2020 East/West: Journal of Ukrainian Studies (ewjus.com) ISSN 2292-7956

Volume VII, No. 2 (2020) 
Simply by not titling the images after their location, McIntyre stands apart from her peers' focus on representing social identity. This choice is often read in the context of Willie Doherty and Paul Seawright's use of detailed and sometimes lengthy captions to interweave narratives of specific locations and public memory in their respective series examining burial and execution sites (Tuck 65-67). McIntyre, however, omits any overt reference to public or collective memory. She notes that her careful positioning of "the viewer and the viewpoint" instead enables the viewer to experience the space in solitude (Tuck 77). Moreover, the lack of guiding text allows the viewer to experience the space from within a form of silence. "There's a contemplative aspect in that," McIntyre explains, "to just allow the place itself to resonate rather than 'speak"' (Tuck 77). Unlike Doherty and Seawright's approach, which engages in a commemorative act of narrative storytelling, McIntyre focuses on the spontaneous, illusory moment of the viewer's encounter.

McIntyre's formal choices echo this desire for lyric pause rather than narrative movement. The composition of "The Mound" series is geometrically minimal, only slightly disrupting the "rule of thirds." While the darkness of the foreground and of the exposure suggests the image was made when there was an excess of light, the layers of fog obscure the time of day and the farther landscape; it is as if time has paused, as if something is incomplete. Whether a viewer sees, for example, a burial site, a neglected field, or the start of a building project depends largely on the viewer's expectations and experience; nothing in the composition, subject matter, or title directs the viewer's affective response toward trauma. Some viewers may respond with anxiety, some with a sense of fear, some with a sense of contemplative calm. In these images, the only "figure" is the viewer, who determines how the place resonates within them.

McIntyre's art, like Meehan and O'Kelly's, invites viewers to consider whether they can resist the powerful urges of ideological and political discourses that over-determine an image's meaning before the moment of encounter. While McIntyre's images do not refer to the Famine, the widespread and lasting impact of deprivation, disappearance, and loss throughout the 1840s and 50s makes it difficult to rule out the possibility that "The Mound" series might evoke a Famine memory for a viewer; the images invite viewers to risk opening themselves to an affective experience in which they may encounter memories of personal and historical loss, without immediately moving toward unidirectional or constricted notions of recovery and mourning. 


\section{UKRAINE}

The eighty-seven years, the geographic distance, and the historical context that separate the Irish and Ukrainian famines result in several issues that challenge attempts at scholarly comparison and yield distinct discourses on commemoration and artistic engagement. ${ }^{23}$ The works we examine here from the Ukrainian context in many ways illuminate more differences than similarities in approaches to famine memory and art-working than what we see in the examples from 0'Kelly, Meehan, and McIntyre. Nevertheless, these works, like those in the Irish context, both engage and disrupt the common tropes and vocabulary found in popular commemoration and resist complete and sanctified narratives. Rather, they work toward fostering artist and audience encounter with the trauma and memory of famine.

Although there were several famines in Ukraine and in other territories of the Soviet Union (notably in the Volga region and Kazakhstan) in the first half of the twentieth century (in the early 1920s and mid-1940s), the 193233 Famine, known as the Holodomor, that claimed the lives of over 3 million in Ukraine is the most prominent in the resulting Ukrainian national memorial paradigm. The exact number of deceased and the causes of the Holodomor are debated, but there is a general consensus in the scholarship that the 1932-33 Famine, which caused a tremendous loss of life, resulted from a number of factors beyond the environmental, namely: Soviet policies of forced collectivization; government efforts to eliminate the peasant class, especially the wealthier class of kulaks; and the restriction of movement and aid to afflicted areas. ${ }^{24}$ The 1932-33 Famine is thus referred to as a terrorfamine (the term "Holodomor" means to kill by hunger) and is considered by many to be an act of genocide by the Soviet state against the Ukrainian people. As in Ireland, many Ukrainians emigrated during and after the Famine. Because public memory of the Famine was suppressed and censored in the Soviet Union, Holodomor memory has developed differently in Ukraine than in the Ukrainian diaspora communities.

\footnotetext{
${ }^{23}$ Comparative studies between the famines in Ireland and Ukraine are rare because of the predominance of the so-called "nationalities paradigm" in academia, in which scholars specialize in one or a few nationalities/languages pertaining to the same region, resulting in rare occurrences of specialists of both Irish and Ukrainian language, history, and culture. The lack of comparative study may also be due to the common practice of producing studies along time frames, where the Famine in Ireland belongs to the "long nineteenth century" and the Ukrainian famine to the "dark twentieth" (Noack et al. 2).

${ }^{24}$ For a discussion on Holodomor historiography, see Andriewsky. Major Englishlanguage histories of the Holodomor include but are not limited to Applebaum, Red Famine; Conquest, Harvest of Sorrow; and Snyder, Bloodlands.
} 
During the Soviet period, individual memory and expressions of witness of the 1932-33 Famine were censored for fifty years and replaced with a totalitarian policy of mass martyrdom. Holodomor memory in Ukraine could be carried only covertly, often in euphemism or extra-communicatively. ${ }^{25}$ Because of their position abroad, free from Soviet censorship, members of the Ukrainian diaspora were able to mourn, communicate memory, commemorate, and establish research institutes with respect to the Holodomor; it was in the diaspora that the term Holodomor was first coined. In Ukraine, the ban on Holodomor memory receded in the 1980s with glasnost' and the Holodomor was appropriated as a national memory under the presidency of Viktor Iushchenko (2005-10). Holodomor commemoration in Ukraine has been referred to by scholars as "the perfect case study of the appropriation of memory," as it presents "the process of collective commemoration from below ... and its political exploitation from above, under laboratory conditions" (Noack et al. 6). And although the event of the Holodomor in Ukraine is less distanced in the past than the Famine in Ireland, and the possibility of living memory, as in Ireland, still exists, famine memory in Ukraine is complicated by memories of other mass traumas in the twentieth century - the Stalinist purges of the late 1930s, the decades of forced labour in Soviet GULAGs, World War II, the Holocaust, the 1986 Chornobyl nuclear disaster, the more recent 2013-14 Revolution of Dignity, the Russian annexation of Crimea, and the Russo-Ukrainian war.

Despite the mainstreaming of Holodomor memory in national narratives and public space since the fall of the Soviet Union, the topic of famine nevertheless remains largely absent from the Ukrainian artistic sphere. In his 2008 essay, "The Holodomor and the Contemporary Ukrainian Writer," Volodymyr Dibrova (himself a creative writer) addresses this surprising lack of artistic output in Ukraine on the topic of famine, pointing to the prolonged absence of public acknowledgement of the Holodomor during the Soviet period compounded with victims' desire to forget, as it was "the only reasonable way of keeping one's sanity and getting on with one's life" (267). It may also be because of this top-down memorial structure that artists in Ukraine avoid a topic that has been appropriated by state language and imagery. ${ }^{26}$ Further, the proximity of the Holodomor, which today claims

${ }^{25}$ For an excellent analysis of literature and film that carried famine memory in the Soviet period, see Starovoyt. Starovoyt analyzes the Soviet memoryscape in the decades after the 1932-33 Famine, drawing out the tensions between Soviet memory policies of "mass martyrdom," forgetting, and the anonymization of trauma with individual attempts at bearing witness produced in art. See also Grabowicz.

26 This absence of artistic work that engages the Holodomor as a subject is made more evident by Ukrainian artists' focus on other traumatic and critical events, such as the current war in the country's east and the emerging willingness to engage less- 
a few survivors, and to which a personal connection to victims is held by many Ukrainians, results in deep emotional pain, making the subject feel unapproachable. Thus, the Holodomor has become somewhat "taboo, a 'nogo' zone for the arts" in Ukraine today (Dibrova 267). This situation is reflected by the works analyzed here, where each participates to some extent in a context outside of the country. We can see both the rupture made by the very creation of these works and the call by their makers for a consideration of ways in which memory of the Holodomor may be held in art today.

In this section we analyze three distinct examples of artistic encounter with the Holodomor: Oksana Zabuzhko, Nataliia Vorozhbyt, and Lydia Bodnar-Balahutrak. These artists engage the topic of famine in explicit terms through prose, theatre performance, and visual art. The prominence of the subject in each piece varies. Although we present them here in the chronological order of their making, we do not claim any sort of developmental process in artistic expression on the subject of famine; instead we consider them signposts of concurrently emerging strategies. As in Ireland, the female body becomes a popular symbol of the colonized nation. As the paradigmatic image in famine commemoration in Ukraine, the suffering woman (as child or mother) symbolizes the nation as a victim (Kis'). In Zabuzhko and Vorozhbyt, the female body takes precedence as both symbol and subject; in both cases, the artist works to engage and disrupt the commemorative trope. In the final section we look at the work of a Ukrainian-American artist, whose work moves away from the confrontational and bodily encounters of Zabuzhko and Vorozhbyt to focus on the natural environment and the after-affects-to use Pollock's terminology - produced by time and distance, themes we see in the Irish examples. In these pieces, the Holodomor is presented through unconventional language and modified imagery, forging unexpected connections in relation to an audience encounter with memory and trauma.

Oksana Zabuzhko's 1996 novel Pol'ovi doslidzhennia z ukrains'koho seksu (Fieldwork in Ukrainian Sex) demonstrates the artistic relationship with trauma that Pollock envisions as a conscious and unconscious "working-toward." Written in the first-person singular, the novel's heroine, Oksana, divulges the inner workings of her psychic and cultural trauma in terms of journeying vis à vis her artistic practice as a poet. Often read as a text that paints Ukraine as "an eternal victim" and uses women's bodies as passive spaces "on which to inscribe, erase, and re-inscribe political and cultural discourses" (Dibrova 273; Blacker 498), Zabuzhko's brief mention

than-popular difficult histories largely absent from official commemoration, such as the Holocaust in Ukraine. This contrasts with what seems to be a greater amount of artwork on the Holodomor produced and shared in the Ukrainian diaspora. 
of the Holodomor may simply be viewed as part of a litany of grievances against the various forces that keep Ukraine and women in a position of subjugation. Yet in the space of the text, the narrator constantly negotiates her own vulnerability and history of abuse with the refutation of a survivor-thus blurring political and cultural discourses with personal experience. As in Meehan's work, Zabuzhko negotiates the relationship between personal and public, the hunger of the individual body and the hunger in history. Brushing elbows with the trope of the bitter woman, Oksana's wry sarcasm and rage disrupts a superficial reading of victimhood. ${ }^{27}$ The character's emphatic yet lyrical speech and interjections of poetry relay a textual space of psychic liminality.

In Fieldwork, Zabuzhko's references to Ukrainian history, including the Holodomor, surface throughout the text as they arise in the heroine's mind. Absent of footnotes and explanations, Fieldwork reads as an intimate diary, confession, or a working through on the part of the lead characterproducing messy and unresolved links with the past instead of historicized and sanitized narratives. Reflecting on the emotional distance of her mother, Oksana contemplates an explanation in terms of her traumatic past, "And what else could she have been if not frigid, a child-survivor of the Famine ... nourished on single stalks of wheat stolen from the field, for which the collective farm guard, catching her once, cut her across the face with a whip-you can still see a thin white thread of scar even now" (Zabuzhko, Fieldwork 148). The scar serves as a trace of the traumatic past-a visual link for Oksana that remains, nevertheless, metaphorical. She is not only othered to the trauma of famine having been born a generation later, but she is also othered to her mother-a distance she ascribes to the isolating effects of trauma.

Because it is the mother whom Zabuzhko casts in the role of famine survivor, the heroine's body, in Kristevan terms, is conditioned in the presymbolic phase in the womb; her drives are bifurcated between death by starvation and survival by cannibalism. ${ }^{28}$ The motif of cannibalism, especially of mother eating child, occupies a significant space, however taboo, in famine memory in both Ukraine and Ireland. In Fieldwork, cannibalism enters the text at different levels that gesture to the trauma of extreme hunger, yet Zabuzhko refrains from linking the topics directly. Oksana alludes to the mother's cannibalism not in times of famine, but as an

\footnotetext{
27 The several instances of explicative language and references to female sexual pleasure and the body in visceral terms shattered conventions for so-called "women's literature," making the novel one of the most critical, controversial, and groundbreaking pieces of post-Soviet Ukrainian literature.

${ }^{28}$ For the ways in which Freud and Kristeva's theories are integrated and grappled with via Ettinger's matrixial model, see Pollock, After-Affects xxix.
} 
adult living in communal housing in the 1970s: "in the kitchen her neighbor, a cook from the local working-class diner . . . threw rags and teeth into Mother's borsch (baby teeth belonging to one of the progeny, perhaps?)" (Zabuzhko, Fieldwork 150). This image refers to both acts of consuming human flesh and non-food (rags) as means of survival; these desecratory acts of eating, however, are made on behalf of an inveterate Soviet woman in times of relative plenty.

Beyond naming cannibalism explicitly, the trauma of deep hunger surfaces in the novel through the all-consuming nature of Oksana's relationship with the Ukrainian artist Mykola. In an emotionally and physically abusive relationship that drives the plot of the novel, these two characters engage in the act of devouring one another both sexually and emotionally. This consumption epitomizes Zabuzhko's project with Fieldwork, where she aims to "examine precisely how that massive, dark, and powerful mainstream of history affects, quite surreptitiously, people's most unconscious behavior, words, and gestures produced in bed" (Hryn and Zabuzhko 17). Thus, throughout the novel, even when the Holodomor is not explicitly approached, trauma linked to famine and hunger surfaces in modes relating to the personal and the intimate.

By navigating traumatic pasts via personal connection and psychological excavation, Zabuzhko eschews the phallic logic of linear historical narratives in favour of emotive and associative lyrical play. ${ }^{29}$ The seemingly spontaneous nature of Oksana's musings replicates thought processes to illustrate the nature of memory. On the one hand, Zabuzhko's reproduction of memory occupies the intimate and personal space of inner monologue. On the other hand, the author frequently and consciously refers to and involves her audience as she makes the address, "Ladies and gentlemen." Zabuzhko's interlocution serves as an invitation for the reader to encounter the working-through of her own trauma. Maria Rewakowicz reads the tension between Zabuzhko's "unmediated self-exposure" and her salutations to the audience as indicative of her "willingness to tell all" (103). This vulnerability works less to construct a monument of national victimhood than to invite the audience to wit(h)ness the past and to search personal memory-even if the narrator feels that her pain can never be completely understood.

Addressing the audience is also a popular strategy for approaching traumatic subjects in contemporary theatre-a communicative method that forges audience connection instead of separateness. Implicating the audience as witness to trauma, if not accomplice, forges participation,

${ }^{29}$ In her 2009 novel, Muzei pokynutykh sekretiv (The Museum of Abandoned Secrets), Zabuzhko takes a more complete, linear, and historical approach to famine memory. Another study is required to better understand Zabuzhko's shift in strategy from lyric to narrative when addressing the Holodomor and Ukrainian history, in general. 
however willing or unwilling. Commissioned by the Royal Shakespeare Company and premiered in London in 2009, Nataliia Vorozhbyt's play Zernokhranylyshche (The Grain Store) directly engages the Holodomor as its main subject and fosters a borderspace via audience encounter (both physical and metaphorical) in the course of its production. In the Irish context, theatre has been a popular medium for artists to engage the Famine of 1845-52 as a topic, yet Vorozhbyt's play is one of the first to emerge from the Ukrainian context. Staged both in London and Ukraine (somewhat later, in 2015), The Grain Store was met with different sets of criticism in each context. Viewed by some as a strength and others as a failing, the play was marked for its ability to transcend the use of traditional and politicized imagery and narratives in representing the Holodomor while nevertheless reproducing common tropes. For example, the main character is Mokrina, the town beauty - a choice by Vorozhbyt that reflects the popular image of the female body, echoing the nation, as a martyr-victim of famine. The plot centres on the fate of a single Ukrainian village in the years of Stalin's first Five Year Plan, which sees the onslaught of forced collectivization and the resulting Famine of 1932-33.

In The Grain Store, Vorozhbyt uses the tensions between hunger and satiety to cultivate an interchange between the past and present, actor and audience, in her approach to conveying the Holodomor. In Michael Boyds's premiere production, the audience enters the theatre to a scene set with some audience members seated at a banquet table on the stage eating an elaborate meal before the start of the production. Philip Holyman remarks that the "somewhat forced spectacle ... unwittingly sets a tone for what is to come, as these privileged guests file back to their seats with the faintly selfsatisfied look of those who have reveled in feasting while those around them are constrained to sit and watch." Here, the audience's participation in the banquet builds a literal connection between the setting of the play and contemporary life.

This form of connection between the past and present comes again at the end of the play, in the final lines, which are recited as a prayer made by an anonymous voice. Through the course of the prayer, the audience infers that the speaker is the daughter of the main character, Mokrina, "Let my mum live longer, who lost her health on the fields of the collective farms and survived famine and German occupation" (Vorozhbit 92). The play ends with Mokrina, the symbolic martyr-victim of famine, figured not as a character of the distant past but as a living agent whose children share the burden of her traumatic memories. Her fate is not frozen in time, nor is her figure cast in bronze. The speaker prays for the souls of her family, living and dead-so many of them swept in the tumultuous currents of the twentieth century: liquidators at Chornobyl, prisoners in the Gulag, casualties of World War II, and a long list of victims of the Holodomor-many of them characters from 
the village. The prayer opens with the speaker's anxiety over a lump discovered at the doctor's office and moves to intercession for her family members. After the devastation felt over the course of the play and the recounting of history and memory, the final line strikes an odd chord: "Lord, please help me lose weight in time for my birthday" (Vorozhbit 92). Previously, the audience may have been reflecting on their own experiences in relation to their privilege and protection in terms of having and not having. But the final line prompts a consideration of the way one views one's own body, especially in terms of the beauty standards and pressures to be thin that dominate many women's lives. Vorozhbyt's message is more honest than shaming; a cure need not exist between pain over famine and pain over one's self; one's relationship with a distant traumatic past may be as fraught and contradictory as it is unresolved.

Having engaged the topic of the Holodomor for most of her career from living in the Ukrainian-American community, Lydia Bodnar-Balahutrak's own aesthetic orientation toward the subject has shifted over the course of her art-working. Much of her earlier work on the subject directly involves the human form, Ukrainian cultural symbols (such as embroidered garments), and religious iconography. In these works, the destruction of bodies in famine and genocide is linked to the desecration of Ukrainian culture. Over time, her practice has moved in the direction of painted collage, where the act of layering, uncovering, and recovering produces a dynamic space of encounter. Like the natural imagery and motifs we see in O'Kelly and McIntyre's works, one of Bodnar-Balahutrak's latest pieces, Will the Grass Grow over It? presents a close view of grass and ground as the dominant image. 
Figure 4. Lydia Bodnar-Balahutrak, Will the Grass Grow over It? Wax, oil, print matter collage / linen, $48 \times 96$ in., 2013; image permission of the artist.

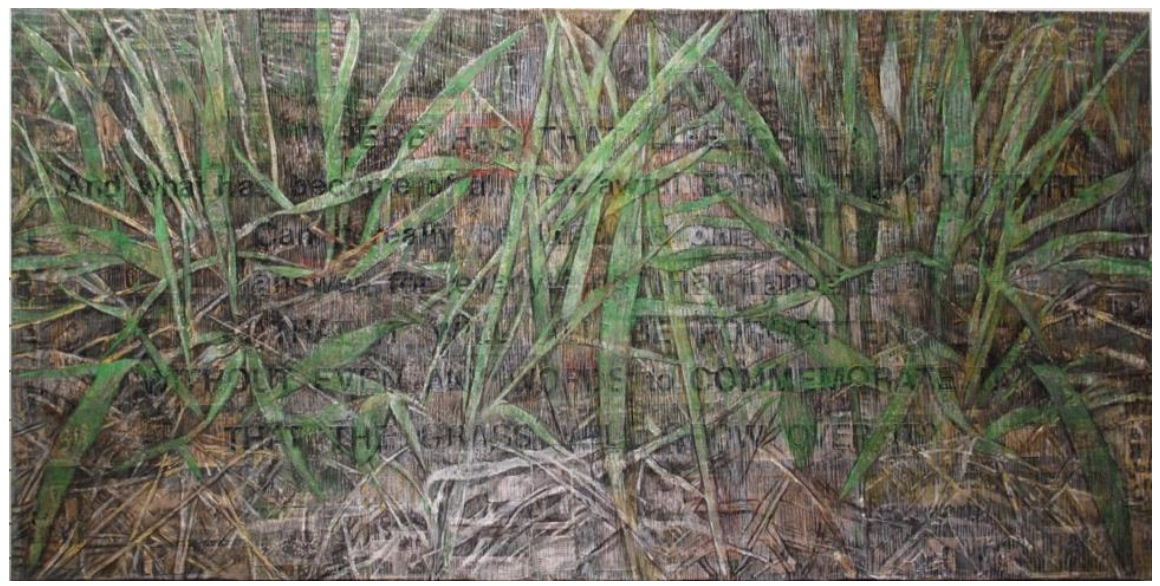

Spanning the 96-inch painted collage is a passage from Vasilii Grossman's 1963 novel, Vse techet (Everything Flows): "Where has that life gone? And what has become of all that awful torment and torture? Can it really be that no one will ever answer for everything that happened? That it will all be forgotten without even any words to commemorate it? That the grass will grow over it?" 30 The questions are asked by the character Anna, a former grain requisitions activist who is both perpetrator and victim. The passage testifies to her witness of the 1932-33 Famine (Holodomor) and ends with her anxiety over the forgetting and the lack of justice for the crime. The metaphor of growing grass that covers a truth buried by the state also relates to the effects of forgetting over the natural progression of time. By posing the question to the viewer, Bodnar-Balahutrak's piece complicates a fear of forgetting with the notion of healing that can be offered through the passing of time and regrowth.

30 "A gde zhe eta zhizn', gde strashnaia muka? Neuzheli nichego ne ostalos'? Neuzheli nikto ne otvetit za eto vse? Vot tak i zabudetsia bez sleda? Travka vyrosla" (Grossman). Bodnar-Balahutrak quotes the passage in its English translation from Conquest's 1986 Harvest of Sorrow: Soviet Collectivization and the Terror-Famine. In Conquest's book, the passage serves as an epigraph to chapter 18, "Responsibilities" (322). A more literal translation of the passage would be: "And where is that life, where is that horrible suffering? Is there really nothing left? Is it possible that no one will answer for all that? And that it will all be forgotten without a trace? The grass has grown over." 
The artist sets this tension between memory and forgetting in the material of the piece, which creates a space for contemplating the subject's tenuous relationship with trauma. From a distance, the aesthetics of nature dominate, but upon closer inspection, the piece is revealed to be composed of media clippings from Western coverage of the Holodomor that are collaged and overlaid with paint. Documentary photos of emaciated famine victims and the language of reportage are piled and buried on the canvas as in the ground.

Figure 4a. Lydia Bodnar-Balahutrak, Detail of Will the Grass Grow over It? Wax, oil, print matter collage / linen, $48 \times 96$ in., 2013; image permission of the artist.

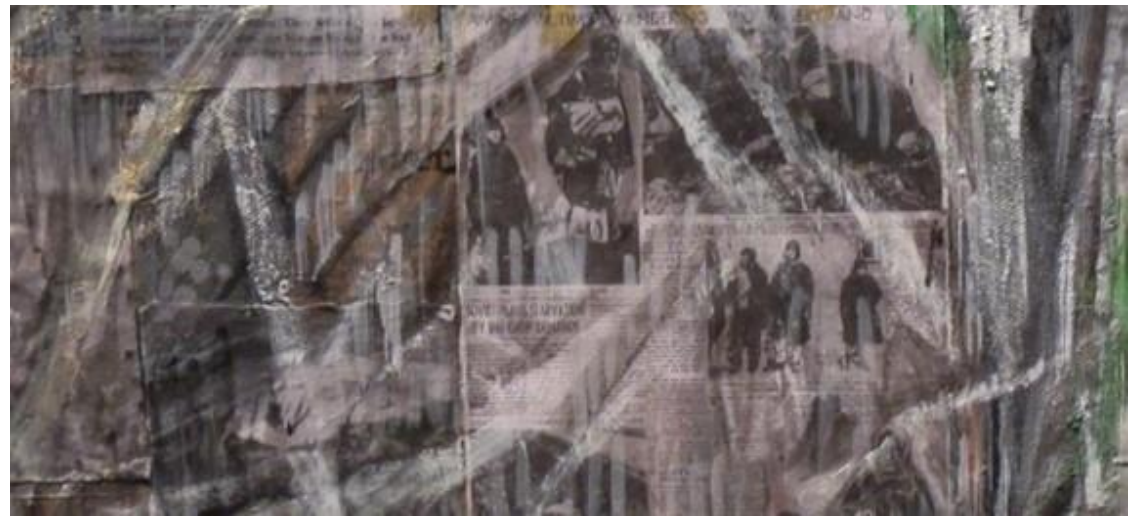

In the process of making the piece, Bodnar-Balahutrak becomes a collector of voices, images, and the media lens on catastrophe. The "burial" of these images in the work mirrors the actual destruction of evidence by the Soviet authorities. Like in 0'Kelly's piece Sanctuary/Wasteland, a lyrical space is created where linear stories are fragmented by the process of collage and produce a mingling of voices and images that overlap, collide, rise, and fade. The artist is aware of her own outsider stance to the Holodomor, yet she demonstrates how we are all implicated as witness es to traumas beyond direct experience through our consumption of not only historical, commemorative, and artistic media, but also, and more frequently, of information presented in the news and social media.

Will the Grass Grow over It? is part of a triptych of collages that engage other traumas of our time: the 9/11 terrorist attacks in New York City and the 2015 Russian annexation of Crimea. Bodnar-Balahutrak thus positions the Holodomor in a multidirectional memorial context, where the distanced trauma of the famine in Ukraine is linked with traumatic events in the artist's 
lifetime. ${ }^{31}$ As Myroslava Mudrak observes, Bodnar-Balahutrak "pays homage to the universal tragedies that today befall many cultures, but identifies these poignant moments of human condition with tragedies that have been visited upon Ukraine in this century ... [including] the artificial famine of 1933." Will the Grass Grow over It? draws the audience (American or otherwise) in through a multidirectional context and implicates audience agency and responsibility. The question posed by the work and the accompanying quote, much like the fictional speaker of Grossman's words, places the audience at the threshold of wit(h)ness: the grass grows but allows neither forgetting nor resolution, while nevertheless posing the question of what time and distance can offer a subjective position toward trauma.

\section{CONCLUSION}

Considering the Irish and Ukrainian famines comparatively, one can witness the beginning of a framework that weaves together trauma studies, psychoanalytic criticism, famine studies, and formal or aesthetic criticism. In the ongoing creative practice of these artists, we see this dynamic synergy of cross-cultural and inter-cultural dialogue. For example, 0'Kelly's one-off site-specific performance, Anáil na Beathe (Breath of Life), created in 2018 in collaboration with other artists at the Schull Workhouse in Cork, connects both local and international histories. Through layers of keening, text, and images, O'Kelly draws together "Places that are affected by famine, by people who are 'moving,' asylum seekers and refugees moving from famine and war-stricken districts" (qtd. in Joyce). Similarly, Paula Stokes' recent Seattle exhibit, 1845: Memento Mori, consisting of 1845 handblown glass potatoes piled into the form of a cairn, or burial marker, begins in the historical realities of the Irish diaspora but extends-through its formal play and through the location of the exhibit-to provoke larger conversations on global migration.

Olesya Zdorovetska, who is originally from Kyiv but now lives in Dublin, also utilizes sound in musical compositions and performances to relay voices affected by traumatic events. ${ }^{32}$ Zdorovetska's compositions draw on Ukrainian poetry-often contemporary texts-and her own memories of traditional Ukrainian songs recited by her grandmother. Informed by her

31 Cf. Michael Rothberg's concept of multidirectional memory.

32 See, for example, "Subconscious Songs from Ukraine," and Zdorovetska's collaboration with Ukrainian poet Liubov Iakymchuk titled "Apricots of DonbasThe Commons" (Olesya Zdorovetska). For more information on Zdorovetska's projects and performances, see http://zdorovetska.com. 
"double life" as a Ukrainian living in Ireland, Zdorovetska considers the crafting of a sister program in the future. A program composed of texts from both Irish and Ukrainian poets, employing a multitude of wit(h)ness voices, would be the most manageable way to engage the Holodomor-for her a deeply personal and painful subject that feels too "white hot" to approach on its own (interview with Zdorovetska, 4 Sept. 2018). Zdorovetska's urge to employ conversant voices across disciplinary and national lines evokes a potential for artists to enact and perform acts of aesthetic wit(h)nessing for communities bearing traces of trauma and in need of recognition.

O'Kelly, Stokes, and Zdorovetska demonstrate that bringing together famine memory-across diverse cultural, linguistic, and historical contexts-is and will continue to be a difficult task for artists who desire to avoid appropriative work that re-inscribes traumatic gestures and systems. The task, then, as Ettinger and Pollock propose, and these artists show, is for critics, readers, and viewers to stand in fascinance-that is, to remain with artworks in a "prolonged aesthetically affecting and learning encounter" (Pollock, After-Affects xxii). In these joint acts of learning encounter, artists need not explicitly share historical references, subject matter, or media practices in order to enter into dialogue. As Herman argues, studying and witnessing psychological trauma is "an inherently political enterprise because it calls attention to the experience of oppressed people" (237). Via commemorative, abstract, and formal artwork, the political nature of traumatic wit(h)nessing becomes a venue for recognizing not only the pain and suffering of individuals and communities but also the multitude of ways in which people sustain life and create culture under extreme conditions.

The work of these artists also raises necessary questions surrounding national and social identity as it relates to collective memory and historical memory; trauma contradicts not only the individual's processing of experience into language, but also any collective attempt to create national narratives and identities. As these famines continue to recede farther into the past for future generations, contemporary and future readers/viewers/critics must consider the extent to which we are, as Pollock writes, the "late-coming witnesses to events that are not our own" (AfterAffects 6). Future generations of artists in Ireland and Ukraine will inevitably create different relationships with each history of famine; with increasing migration and cross-cultural dialogue, the identities, languages, and cultural traditions of these artists will shape the ways in which other memories and histories are interwoven into the Irish and Ukrainian contexts. The work analyzed above is not presented as an end-point of famine engagement in these contexts, but rather as a signpost of what is to come: in opening up the form of commemoration and artistic engagement, these artists also open up the field-or the art world-itself. 
Works Cited

Andriewsky, Olga. "Towards a Decentered History: The Study of the Holodomor and Ukrainian Historiography." Contextualizing the Holodomor: The Impact of Thirty Years of Ukrainian Famine Studies, edited by Andrij Makuch and Frank Sysyn, Canadian Institute of Ukrainian Studies P, 2015, pp. 14-48.

Applebaum, Anne. Red Famine: Stalin's War on Ukraine. Doubleday, 2017.

Blacker, Uilleam. "Nation, Body, Home: Gender and National Identity in the Work of Oksana Zabuzhko." The Modern Language Review, vol. 105, no. 2, 2010, pp. 487501. DOI: $10.2307 / 25698706$

Bodnar-Balahutrak, Lydia. Will the Grass Grow over It? 2013, http://www.lydiabodnarbalahutrak.com. Accessed 25 Apr. 2020.

Boland, Eavan. "Famine Roads." Irish Hunger: Personal Reflections on the Legacy of the Famine, edited by Tom Hayden, Roberts Rinehart Publishers, 1997, pp. 212-222.

Carville, Justin. Photography and Ireland. Reaktion Books, 2011.

Conquest, Robert. Harvest of Sorrow: Soviet Collectivization and the Terror-Famine. Oxford UP, 1986.

Dibrova, Volodymyr. "The Holodomor and the Contemporary Ukrainian Writer." After the Holodomor: The Enduring Impact of the Great Famine on Ukraine, Special Issue of Harvard Ukrainian Studies, vol. 30, no. 1/4, 2008, pp. 265-76.

Ettinger, Bracha L. "The Red Cow Effect: The Metramorphosis of Hallowing the Hollow and Hollowing the Hallow." He Said, She Says: An RSVP to the Male Text, edited by Mica Howe and Sarah Appleton Aguiar, Fairleigh Dickinson UP, 2001, pp. 57-88.

Fisher, Janina. Healing the Fragmented Selves of Trauma Survivors: Overcoming Internal Self-Alienation. Routledge, 2017.

Grabowicz, George. "The Holodomor and Memory." Hunger by Design: The Great Famine and Its Soviet Context, edited by Halyna Hryn, Harvard Ukrainian Research Institute, 2008, pp. 131-46.

Graham, Colin. "'Evidence of the Future." Where Are All the People?, edited by Karen Downey, Belfast Exposed Photography, 2010.

Gregory, Ian N., and Paul S. Ell. "Analyzing Spatiotemporal Change by Use of National Historical Geographical Information Systems: Population Change during and after the Great Irish Famine." Historical Methods, vol. 38, no. 4, Fall 2005, pp. 14967. DOI: $10.3200 /$ HMTS.38.4.149-167

Grossman, Vasilii. Vse techet, Kievskaia gorodskaia biblioteka, https://lib.misto.kiev.ua/PROZA/GROSSMAN/techet.dhtml. Accessed 1 July 2019.

Herman, Judith. Trauma and Recovery: The Aftermath of Violence-from Domestic Abuse to Political Terror. Basic Books, 1997.

Holyman, Philip. "Reviews: The Grain Store (RSC)." What's on Stage, 25 Sept. 2009, www.whatsonstage.com/west-end-theatre/reviews/the-grain-storersc_15754.html. Accessed 25 Apr. 2020.

Hryn, Halyna, and Oksana Zabuzhko. "A Conversation with Oksana Zabuzhko." Agni, no. 53, 2001, pp. 17-22. 
Joyce, Anna. "Schull to Relive Famine Experience at Workhouse." The Irish Times, 19 July 2018, https://www.irishtimes.com/culture/heritage/schull-to-relivefamine-experience-at-workhouse-1.3569353. Accessed 25 Apr. 2020.

Kelleher, Margaret. The Feminization of Famine: Expressions of the Inexpressible? Duke UP, 1997.

Kelly, Niamh Ann. Ultimate Witnesses: The Visual Culture of Death, Burial, \& Mourning in Famine Ireland. Quinnipiac UP, 2017.

Kis', Oksana. “Chomu ukrains'ka zhinka ie symvolom Holodomoru?" Hromads'ke Radio, 31 May 2017, www.hromadske.radio/podcasts/rankova-hvylya/chomuukrayinska-zhinka-ye-symvolom-golodomoru. Accessed 25 Apr. 2020.

Kosofsky Sedgwick, Eve. Touching, Feeling: Affect, Pedagogy, Performativity. Duke UP, 2003.

Lennon, Joseph. "The Starvation of a Man: Terence MacSwiney and Famine Memory." Memory Ireland. Vol. 3: The Famine and the Troubles, edited by Oona Frawley, Syracuse UP, 2014, pp. 59-90.

Lloyd, David. "Adulteration and the Nation." Anomalous States: Irish Writing in the Postcolonial Moment, Duke UP, 1993, pp. 88-124.

---. Ireland after History. Notre Dame UP, 1999.

---. "The Memory of Hunger." Irish Hunger: Personal Reflections on the Legacy of the Famine, edited by Tom Hayden, Roberts Rinehart Publishers, 1997.

Mark-Fitzgerald, Emily. "The Irish Famine and Commemorative Culture." Holodomor and Mór: Histories, Memories and Representations of Famine in Ukraine and Ireland, edited by Christian Noack et al., Anthem Press, 2012, pp. 145-64.

---. "Photography and the Visual Legacy of Famine." Memory Ireland. Vol. 3: The Famine and the Troubles, edited by Oona Frawley, Syracuse UP, 2014, pp. 12137.

McIntyre, Mary. “The Mound, I.” A Contemporary Sublime: Photographs 1998-2012. The MAC Belfast, 2013, p. 112.

---. "The Mound, II." A Contemporary Sublime: Photographs 1998-2012. The MAC Belfast, 2013, p. 113.

Meehan, Paula. Reading the Sky. Beaver Row Press, 1986.

Mudrak, Myroslava. "Tangled Roots: 'Where Have All the Mallows Gone?'” Tangled Roots Exhibition, Bowling Green State University, 1995.

Noack, Christian, et al., eds. Holodomor and Gorta Mór: Histories, Memories and Representations of Famine in Ukraine and Ireland. Anthem Press, 2012.

o'Kelly, Alanna. Anáil na Beathe. Schull Workhouse, Co. Cork, for Coming Home: Art and The Great Hunger at Uillinn: West Cork Arts Centre. 21 July 2018.

---. Sanctuary/Wasteland. 1994. Collection Irish Museum of Modern Art, Purchase 1997.

Pollock, Griselda. After-Affects / After-Images: Trauma and Aesthetic Transformation in the Virtual Feminist Museum. Manchester UP, 2013.

---. "Thinking the Feminine: Aesthetic Practice As Introduction to Bracha Ettinger and the Concepts of Matrix and Metramorphosis." Theory, Culture \& Society, vol. 21, no. 1, 2004, pp. 5-65. DOI: 10.1177/0263276404040479

Randolph, Jody Allen. "The Body Politic: A Conversation with Paula Meehan." An Sionnach: A Journal of Literature, Culture, and the Arts, vol. 5, nos. 1 and 2, 2009, pp. 239-71. 
Reginio, Robert, et al., eds. Samuel Beckett and Contemporary Art. Ibidem Press, 2017. Reiff, David. In Praise of Forgetting: Historical Memory and Its Ironies. Yale UP, 2016. Rewakowicz, Maria. Ukraine's Quest for Identity: Embracing Cultural Hybridity in Literary Imagination, 1991-2011. Lexington Books, 2018.

Rothberg, Michael. Multidirectional Memory: Remembering the Holocaust in the Age of Decolonization. Stanford UP, 2009.

Snyder, Timothy. Bloodlands: Europe between Hitler and Stalin. The Bodley Head, 2010.

Starovoyt, Iryna. "Holodomor, Amnesia, and Memory-(Re)Making in Post-War Ukrainian Literature and Film." Journal of Soviet and Post-Soviet Politics and Society, vol. 1, no. 5, 2015, pp. 341-65.

Stokes, Paula. 1845: Memento Mori. METHOD Gallery, 2019.

Tuck, Sarah. After the Agreement: Contemporary Photography in Northern Ireland. Black Dog Publishing, 2015.

Valente, Joseph. "Ethnonostalgia: Irish Hunger and Traumatic Memory." Memory Ireland. Vol. 3: The Famine and the Troubles, edited by Oona Frawley, Syracuse UP, 2014, pp. 174-92.

Voigt, Ellen Bryan. The Flexible Lyric. Georgia UP, 1999.

Vorozhbit, Natal'ia (Nataliia Vorozhbyt). The Grain Store. Translated by Sasha Dugdale, Nick Hern Books, 2009.

Zabuzhko, Oksana. Fieldwork in Ukrainian Sex. Translated by Halyna Hryn, Amazon Crossing, 2011.

---. The Museum of Abandoned Secrets. Translated by Nina Shevchuk-Murray, Amazon Crossing, 2012.

Zdorovetska, Olesya. Olesya Zdorovetska, http://zdorovetska.com. Accessed 25 Apr. 2020.

---. Personal interview. 4 Sept. 2018. 